\title{
Annual Reproductive Cycle of Acheilognathus majusculus, a Korean Endemic Species
}

\author{
Jin-Yeong Lim and Won-Kyo Lee \\ Dept. of Aqualife Science, Chonnam National University, Yeosu 550-749, Korea
}

\begin{abstract}
An experiment was conducted to investigate the annual reproductive cycle of a Korean endemic species, Acheilognathus majusculus, from Jeokseong-myeon located in Seomjin River. The reproductive cycle is examined histologically regarding water temperature and day length of the habitat, the gonadosomatic index (GSI), the female ovipositor length index (OLI), monthly variation in egg diameter distribution, and developmental characteristics of female and male gonads. The maximum GSI was found in $19.21 \pm 2.32$ and $6.90 \pm 0.53$ for female and male respectively when water temperature $\left(14^{\circ} \mathrm{C}\right)$ and day length $(11.1 \mathrm{hr})$ began to rise. On the other hand, the minimum level was reached during August $(1.87 \pm 0.67$ for female and $0.88 \pm 0.50$ for male). No samples represent with measurable ovipositor between September and November, while the longest ovipositor length index was in April (79.68 $4.69 \%)$. We compared and calculated the stages of testis and ovary development process in order to determine the germ cell development characteristics and the reproductive cycle. According to the result, we classified the female Acheilognathus majusculus reproductive cycle into four stages: Ripe (April) and spawning phase (May to June), degenerative phase (July), growing phase (August to December), and mature phase (January to March). The annual reproductive cycle of male Acheilognathus majusculus was categorized into five stages viz. Ripe and spawning phase (May to June), degenerative phase (July to August), resting phase (September to November), growing phase (December to February), and mature phase (March to April).
\end{abstract}

Key words : Acheilognathus majusculus, Gonadosomatic index(GSI), Spawning, Reproductive cycle

\section{INTRODUCTION}

There are two genus and fourteen species of Acheilognathinae subfamily known to inhabit in South Korea. 9 out of 14 Acheilognathinae subfamily species are endemic in Korean, consequently they have prime biological and genetical value (Kim et al., 2005). An endemic species is specialized to live only in a given area. Therefore, its extinction means total elimination of the genetic resource. Since Acheilognathinae subfamily fishes usually inhabit freshwater, they are inherently vulnerable to development and industrializa- tion. Among them, Rhodeus hondae is already verified to be extinct.

Not only habitat protection, but also defining reproductive characteristics and artificial seed production are essential in order to conserve endangered species. A few studies have been reported on Acheilognathinae subfamily reproduction: Reproductive cycle of Rhodeus uyekii (An, 1995), Change of external reproductive parameters according to sexual maturation of the Striped Bitterling, Acheilognathus yamatsutae (Jin et al., 2008), Abnormality of reproduction and organ structure of the Oily Bitterling, Acheilognathus koreensis from Isa Stream (Jugn et al., 2006), and Sexual

\footnotetext{
Manuscript received September 16, 2017, Received in revised form September 20, 2017, Accepted September 23, 2017

${ }^{\dagger}$ Corresponding Author: Won-Kyo Lee, Department of Aqualife Science, College of Fisheries and Ocean Science, Chonnam National University, Yeosu 550-749, Korea. Tel: +82-61-659-7161, E-mail: wklee196@jnu.ac.kr

This is an Open Access article distributed under the terms of the Creative Commons Attribution Non-Commercial License (http:// creativecommons.org/licenses/by-nc/3.0) which permits unrestricted non-commercial use, distribution, and reproduction in any medium, provided the original work is properly cited.
} 
Maturation and the spawning season of the Korean Bitterling, Acheilognathus signifier in upper reachs of the Hongchen River(Baek et al., 2003).

Acheilognathus majusculus is a Korean endemic species inhabit in Seomjin River, Bosung River, and Nakdong River in the southern areas of Korean peninsular. Until now, studies on the reproduction of Acheilognathus majusculus have only been conducted on egg development and initial life cycle (Kim et al., 2014).

In the present study, we aimed to explore the reproductive cycle of Acheilognathus majusculus, a Korean endemic species, to lay grounds for species conservation and genetic resource procurement.

\section{MATERIALS AND METHOD}

\section{Sampling}

15-20 of each female and male Acheilognathus majusculus were collected from upper Seomjin River, Gwejeong Village, Jeoksongmyun, Sunchanggun, Jeollabukdo ( $35^{\circ} 24^{\prime}$ $\left.45 \mathrm{~N}, 127^{\circ} 13^{\prime} 41^{\prime \prime} \mathrm{E}\right)$ from May 2016 to June 2017 using weir traps and skimming nets. Collected samples were delivered to the laboratory facility alive, to be dissected carefully.

\section{Environment investigation}

Water temperature was measured on 10th-20th of every month from the sampling site. However, in order to analyze the monthly temperature precisely, we referred to Seomjin River Water Management Research Center's data. For day length, we recorded and converted the day length of every $15^{\text {th }}$ on Sunchang Meteorological Observatory database.

\section{Histological method}

Samples were measured until $0.1 \mathrm{~cm}$ unit scale for length and $0.01 \mathrm{~g}$ unit scale for weight. The ovipositor length was measured until $0.01 \mathrm{~mm}$ unit scale using Vernier calipers, while the ovipositor length index was calculated using Jung et al (2014) method (elongated ovipositor length $\times 100 /$ total length). Then the abdomen was dissected to weigh the gonads until $0.001 \mathrm{~g}$ unit scale.

We calculated the gonadosomatic index from N'Da \& Deniel method (1993) (gonad weight / body weight $\times 100$ ) in order to examine the monthly variation in gonad maturation status.

Excavated gonads were fixed for 24 hours in Bouin's solution (picric acid:formalin:acetic acid = 15:5:1), embedded in paraffin and sliced into 5-7 $\mu \mathrm{m}$ of serial sections, and then double-stained with hematoxylin and eosin. The female reproductive cycle was defined using frequency of follicular development stages in the ovaries, while male reproductive cycle was defined using frequency of lobules with the progress of spermatogenesis stages in the testis.

\section{RESULTS}

\section{Monthly variation in water temperature and day} length

Monthly variation in water temperature and day length of the sampling site are described in Fig. 1A. The onset of study water temperature was $20^{\circ} \mathrm{C}$, and $20.3^{\circ} \mathrm{C}$ a year after. Water temperature was $25.2^{\circ} \mathrm{C}$ and $25.5^{\circ} \mathrm{C}$ in June 2016 and 2017 respectively. It increased to $28^{\circ} \mathrm{C}$ in July and $30^{\circ} \mathrm{C}$ in August 2016. The temperature dropped from $24^{\circ} \mathrm{C}$ in September to $20.3^{\circ} \mathrm{C}$ in October, then $15.8^{\circ} \mathrm{C}$ in November, and $6.6^{\circ} \mathrm{C}$ in December. Lowest temperature was recorded $3.7^{\circ} \mathrm{C}$ in January 2017 . It rebounded back starting $4.6^{\circ} \mathrm{C}$ in February then $7.9^{\circ} \mathrm{C}$ in March and $15.0^{\circ} \mathrm{C}$ in April.

The day length was $13.1 \mathrm{hr}$ at the onset of study (May 2016), and the annual longest was found 14.6hr during June. Day length decreased to $10.7 \mathrm{hr}$ in September, and the annual shortest day length was recorded in 8.6hr during December. It was $9.3 \mathrm{hr}$ and $14.4 \mathrm{hr}$ in January and June 2017 when the study was completed.

\section{Monthly variation in gonadosomatic index (GSI)}

The gonadosomatic index of Acheilognathus majusculus is shown in Fig. 1B. For female, the measurement started 

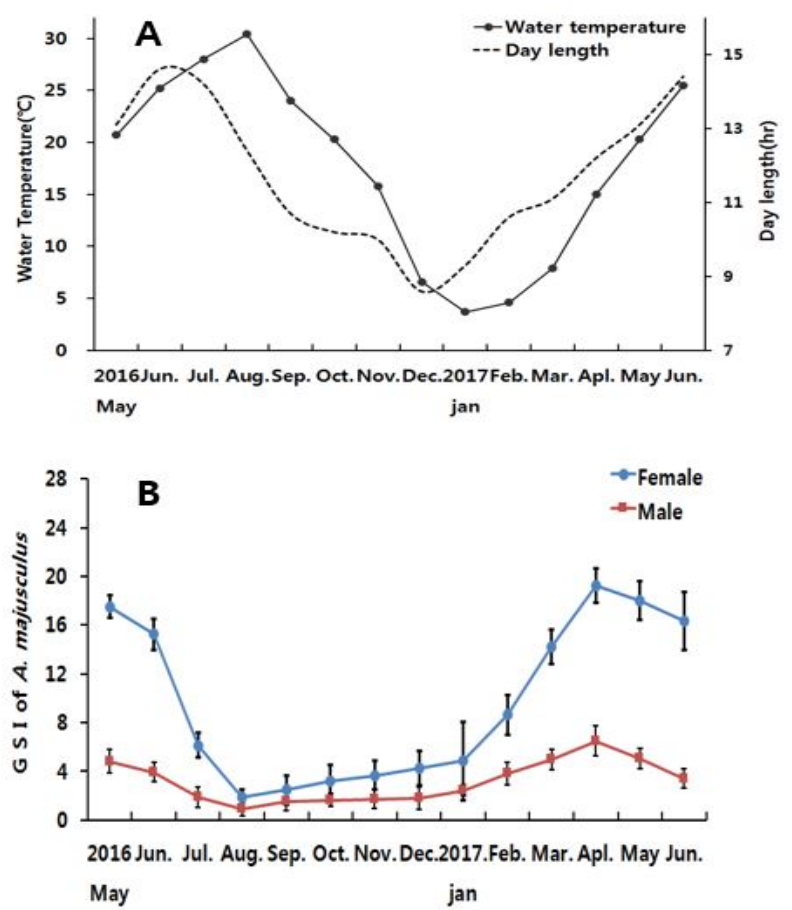

Fig. 1. Monthly variations of water temperature and day length (A), and Gonadosomatic (GSI) of female and male bitterling, Acheilognathus majusculus (B). (Circles and bars indicate the mean and standard error).

from 17.53 \pm 0.89 in May 2016 and $18.02 \pm 1.58$ in May 2017 . In June, it decreased to $15.26 \pm 1.26$ and $16.35 \pm 1.41$ respectively. In July 2016 GSI value dramatically dropped to $6.16 \pm 1.03$, and the annual minimum GSI value was found $1.87 \pm 0.67$ in August when the water temperature began to rise. Then GSI gradually increased to $2.47 \pm 1.22$ in September, $3.21 \pm 1.30$ in October, $3.66 \pm 1.19$ in November, $4.27 \pm$ 1.41 in December, and $4.85 \pm 2.25$ in January. It further increased to $8.65 \pm 1.62$ in February, 14.21 \pm 1.4 in March, and reached the annual maximum of $19.21 \pm 2.32$ in April.

Male GSI for May 2016 and 2017 was $4.62 \pm 0.42$ and $5.02 \pm 0.32$ respectively, while in June the value slightly decreased to $3.94 \pm 0.80$ and $3.42 \pm 0.61$, respectively. In July the value was even lower $(2.32 \pm 0.80)$, and marked the lowest $(0.87 \pm 0.50)$ in August. Then it rises to $1.51 \pm 0.45$ in September, $1.64 \pm 0.53$ in October, $1.75 \pm 0.32$ in November,
$1.80 \pm 0.29$ in December, and 2.46 \pm 0.43 in January. It further increased in February to $3.84 \pm 0.92$, and reached the highest (6.90 \pm 0.53$)$ in April.

\section{Monthly Variation in Female External Ovipositor} Length (OLI)

The external ovipositor length in female is demonstrated in Fig. 2. It started with $75.22 \pm 6.22 \%$ in May 2016 and $74.52 \pm 4.53 \%$ in May 2017. Then the next month it slightly shrank to $72.51 \pm 4.65 \%$ and $69.78 \pm 6.22 \%$ respectively. In July, the length dramatically decreased to $21.54 \pm 7.72 \%$, then there were no samples with measurable ovipositor through August to November. In December samples with ovipositors started to appear again, measuring $25.65 \pm 4.25 \%$. Then the length gradually increased to $32.74 \pm 6.24 \%, 40.1 \pm 8.01 \%$, $64.35 \pm 5.62 \%$, and $79.68 \pm 4.69 \%$ in January, February, March and April respectively.

\section{Monthly variation of oocyte diameters in the ova-} ries

The diameters of oocytes with yolk vesicles, yolk globules and hydrated stages were measured monthly (Fig. 3).

The oocytes with yolk vesicle appeared monthly during the study period. The diameters of yolk vesicle stage oocytes were $657.35 \pm 41.25 \mu \mathrm{m}$ in May 2016 and $685.12 \pm 48.16 \mu \mathrm{m}$ in May 2017, and 665.57 $\pm 37.58 \mu \mathrm{m}$ in June 2016 and $670.79 \pm 58.36$ $\mu \mathrm{m}$ in June 2017. The diameters of yolk vesicle stage oocytes

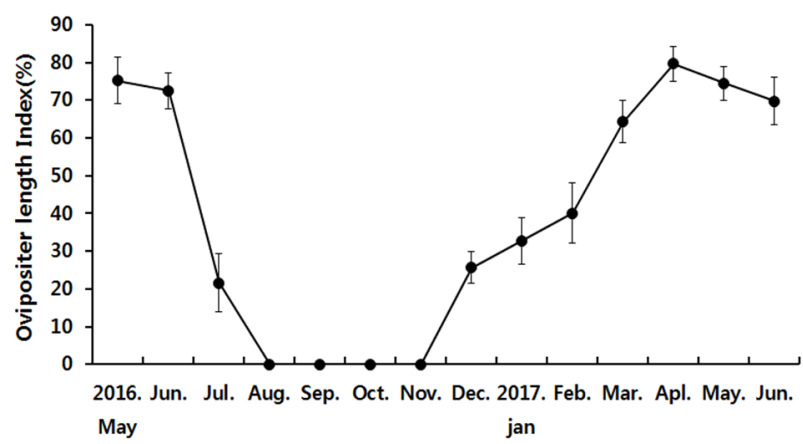

Fig. 2. Monthly change in ovipositor length index (OLI) of female Acheilognathus majusculus. 


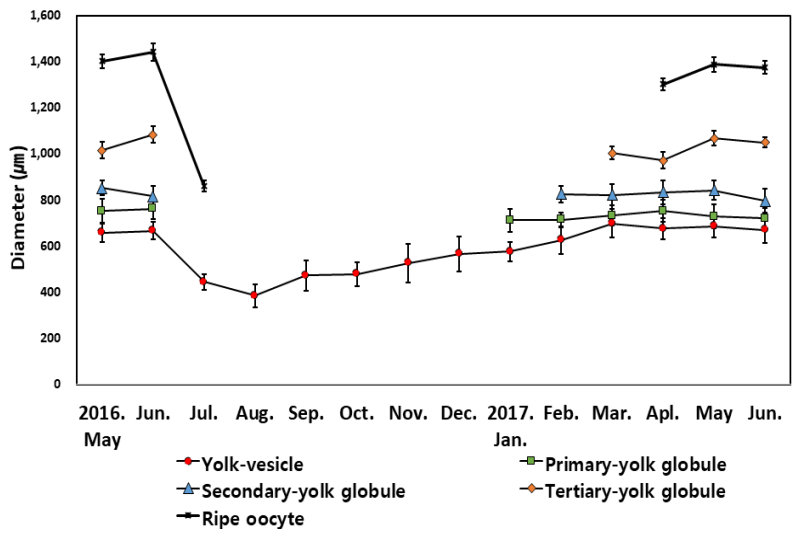

Fig. 3. Monthly variations of oocyte diameter in the female bittering, Acheilognathus majusculus.

decreased to $443.79 \pm 32.58 \mu \mathrm{m}$ in July 2016 , and became the annual smallest of $383.67 \pm 48.21 \mu \mathrm{m}$ in August. From September it started to grow $471.38 \pm 65.24 \mu \mathrm{m}$, reaching $565.71 \pm 75.24 \mu \mathrm{m}$ in December. The diameters of yolk vesicle stage oocytes gradually increased to $576.16 \pm 42.47 \mu \mathrm{m}$ in January, $625.98 \pm 59.42 \mu \mathrm{m}$ in February, $698.59 \pm 61.25 \mu \mathrm{m}$ in March, and 675.96 $\pm 45.24 \mu \mathrm{min}$ April.

Primary yolk globule stage oocytes appeared from January to June. The diameters of primary yolk globule stage oocytes were lowest at $711.25 \pm 48.47 \mu \mathrm{m}$ in January 2017, The largest size of diameter was $761.58 \pm 44.37 \mu \mathrm{m}$ in June 2016 and $751.26 \pm 48.15 \mu \mathrm{m}$ in April 2017 during the experimental period.

Secondary yolk globule stage oocytes appeared from February to June. The diameters of secondary yolk globule stage oocytes were lowest at $796.15 \pm 52.22 \mu \mathrm{m}$ in June 2017, The largest size of diameter was $851.26 \pm 31.74 \mu \mathrm{m}$ in May 2016 and $842.10 \pm 43.25 \mu \mathrm{m}$ in May 2017 during the experimental period.

Tertiary yolk globule stage oocytes appeared from March to June. The diameters of Tertiary yolk globule stage oocytes were lowest at $971.95 \pm 35.22 \mu \mathrm{m}$ in April 2017. The largest size of diameter was $1,082.47 \pm 35.85 \mu \mathrm{m}$ in June 2016 and 1,066.43 $\pm 32.44 \mu \mathrm{m}$ in May 2017 during the study period.

Ripe(hydrated) oocytes appeared from April to July.
The diameters of hydrated oocytes were lowest at $861.04 \pm$ $24.86 \mu \mathrm{m}$ in July 2017. In July, hydrated oocytes not only were smallest in the size but also showed limited number of samples in the ovary. The largest size of diameter was $1,441.95 \pm 37.96 \mu \mathrm{m}$ in June 2016 and 1,388.14 $\pm 31.57 \mu \mathrm{m}$ in May 2017.

\section{Histological changes of ovaries and the repro- ductive cycle}

Development stages of oocyte and follicles were histologically examined (Fig. 4), calculated as frequencies, and female reproductive cycle (Fig. 5).

The frequencies of oocytes with growing stage (chromatin-nucleolus, peri-nucleolus and yolk-vesicle) were 37.1\% in May 2016 and 35.58\% in May 2017. The frequency slightly increased the next month, comprising $41.13 \%$ and $37.76 \%$ respectively. In July 2016, the rate of frequency rapidly increased to $96.8 \%$, and reached $100 \%$ from October to December. In January 2017, the frequencies of oocytes with growing stage started to decrease $84.45 \%$, then $73.3 \%$ in February, 55.87\% in March, and 37.9\% in April.

The maturing stage oocytes (Primary yolk globule, Secondary yolk globule and tertiary yolk globule) were appeared from January to June. In January 2017, there was only primary yolk globule stage oocyte among the maturing stage oocytes, and the frequency of maturing stage oocytes was $15.55 \%$. In February 2017, there were primary yolk globule stage oocyte and secondary yolk globule stage oocyte, and the frequency of maturing stage oocytes was $26.7 \%$. In March 2017, tertiary yolk globule stage oocyte appeared in the ovary, and the frequency of maturing stage oocytes was $44.13 \%$.

The ripe (hydrated) stage oocytes appeared from April to July. In April 2017, the frequency of maturing stage oocytes and ripe stage oocytes was $62.17 \%$ and $19.86 \%$, respectively. In May and June, ovulated follicles appeared in the ovary.

The frequency of ovulated follicles in May 2016, June 

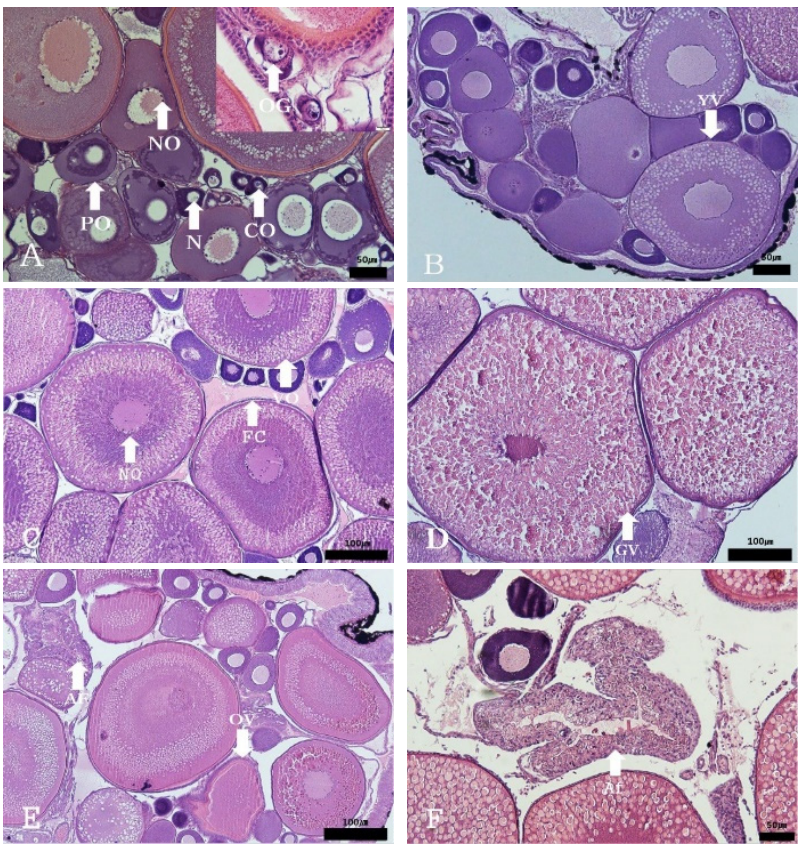

Fig. 4. Ovarian development stage of the large striped bitterling, Acheilognathus majusculus. A: Growing phase. Note the oogonia and oocytes in chromatin-stage and peri-nucleolus. B: Growing phase. The oocytes various development. Note the yolk vesicles found in ooplasm. C: Mature stage. Note the numerous yolk globule in ooplasm and increase of oocyte diameter. D: Ripe and spawning phase. Note the germinal vesicle. E: Ripe and spawning phase. Note the hydration oocyte and ovulation follicle. F: Degenerative phase. Showing the atretic follicle. AF: atretic follicle; Co: chromatin nucleolus Fc: follicle cell; Gv: germinal vesicle; N: nucleus; No: nucleolus; Og: oogonia; Po: perinucleolus oocyte; Vo: vitellogenic oocyte; Yv: Yolk vesicle; Scale bars: $50-100 \mu \mathrm{m}$.

2016, May 2017 and June 2017 was 5.05\%, 8.43\%, 5\% and $9.65 \%$ respectively. In July atretic follicles appeared in the ovary.

\section{Histological changes of testes and the reproduc-} tive cycle

The progress of spermatogenesis stages in the testis were histologically examined (Fig. 6), calculated as frequencies, and male reproductive cycle (Fig. 7).

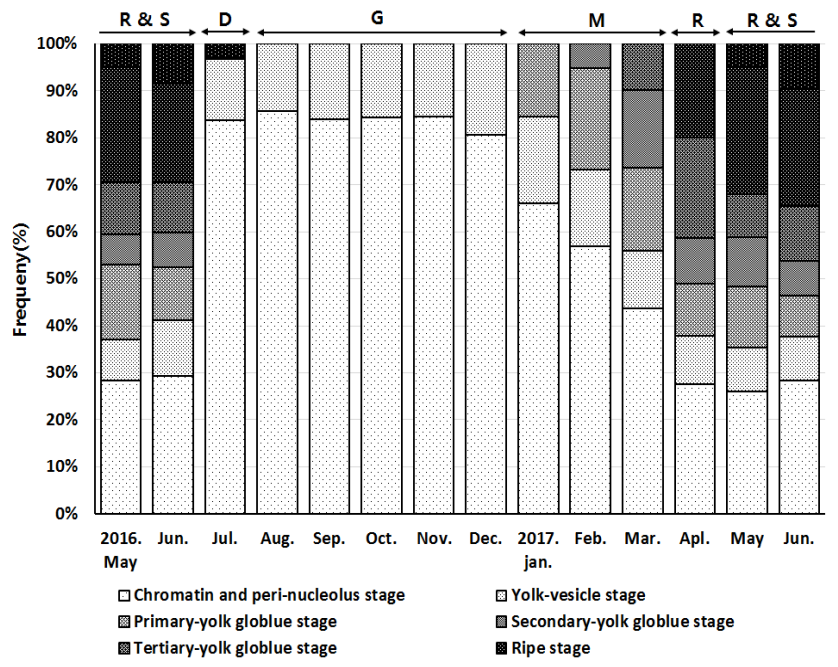

Fig. 5. Monthly change in proportional frequency of ovarian stage in Acheilognathus majusculus. D: Degenerative, G: Growing, M: Mature, R: Ripe, R \& S: Ripe and Spent.

In April and June, the seminiferous tubules of testes were fully filled with spermatozoa. From July to August, a small number of sperm remained in the lumen of seminiferous tubules, after ejaculation. In September, newly dividing spermatogonia started to appear in testes. From October to November, proliferation of spermatogonia continued and the seminiferous tubules with the cyst of primary spermatocyte appeared in the testes. From December to January, the seminiferous tubules were filled with primary spermatocytes and secondary spermatocytes. In February and March, the seminiferous tubules with spermatid appeared and the testes were full of cells of all stages of meiosis.

\section{DISCUSSION}

Most fish spawn in the period of maximal possibility of offspring survival, since successful prosperity is the key strategy for species continuity. Fish that inhabits middle latitude regions have seasonal spawning phase, and they repeat annually (Lee et al., 1984). Germ cell division, growth, maturation, spawning, and degeneration are involved in the reproductive cycle. The reproductive cycle of fish species is collectively 


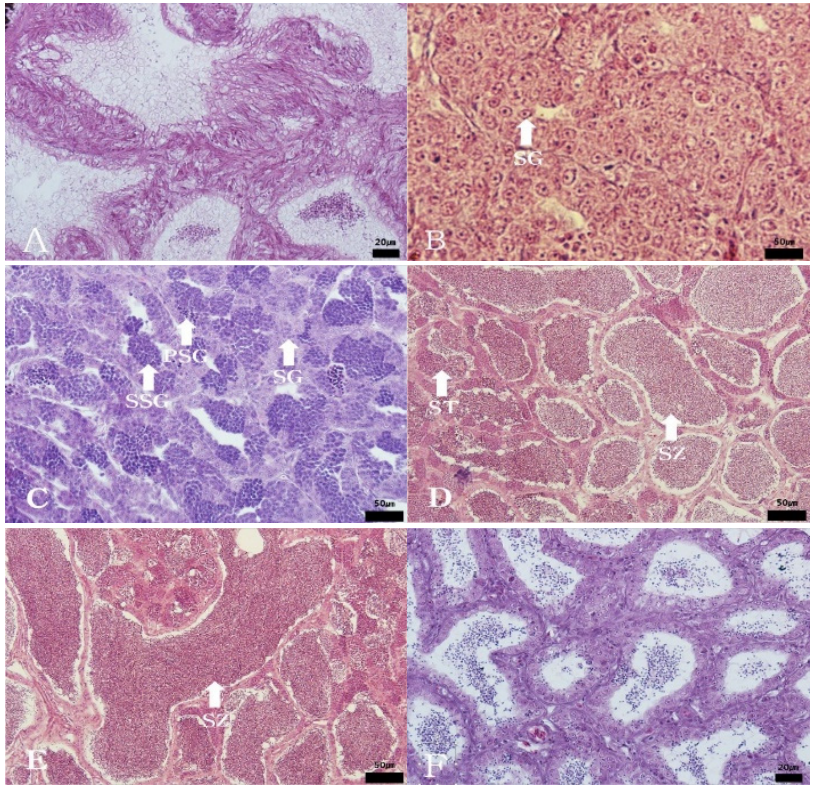

Fig. 6. Testicular development stage of the large striped bitterling, Acheilognathus majusculus. A: Degenerative phase. Degenerative germ cell B: Resting phase. Spermatogoina were multiplied in the seminiferous tubule. C: Growing phase. The spermatogonia and spermatocyte filled the seminiferous tubule. D: Mature phase. Testis become withering spermatid and spermatozoa. E: Ripe phase. Note the numerous basophilic spermatozoa. F: Spent phase. Note the undischarged spermatozoa. Sg: spermatogonia; $\mathrm{St}$ : spermatid; Sz: spermatozoa; Ssc: secondary spermatocyte; Psc: Primary spermatocyte; Scale bars: $20-50 \mu \mathrm{m}$.

defined with regards to external genitalia morphology, gonadosomatic (GSI) changes, and histologic clues of oocyte and sperm development.

The GSI of Acheilognathinae subfamily fish is highest right before or in the start of spawning, and maintains relatively high level during spawning. But right after the process the GSI drops to the annual lowest, with gradual rebound. However, the timing and duration are different from species to species. Rhodeus uyekii's GSI is highest in May, drops from July and reaches the lowest during August (An, 1995). Acheilognathus signifer's GSI maximizes in April and gradually decreases until August (Baek et al., 2003).

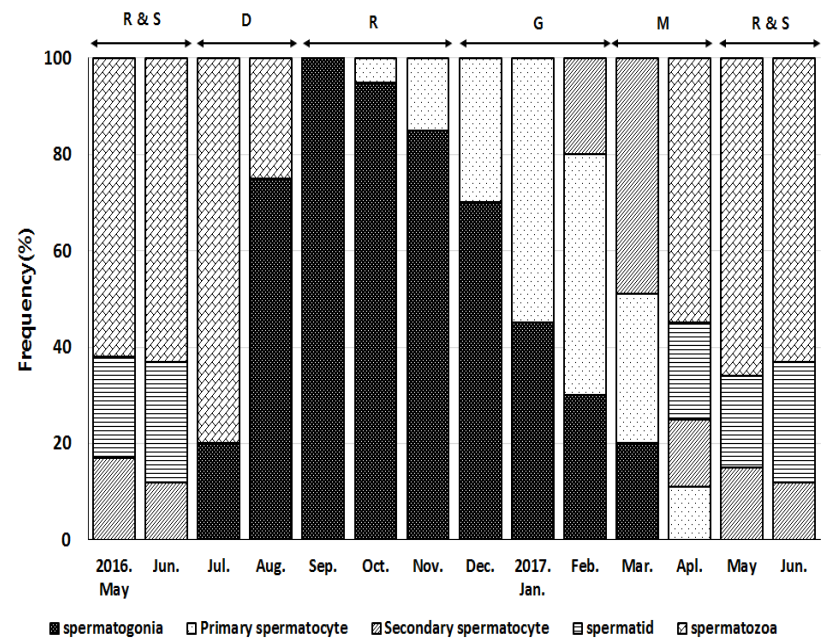

Fig. 7. Monthly change in proportional frequency of testicular stage in Acheilognathus majusculus. D: Degenerative, G: Growing, M: Mature, R \& S: Ripe and Spent, R: Resting.

Acheilognathus yamatsutae's GSI is highest in February and reaches the lowest between June and August (Jin, 2008). For Aceilognathus majusculus, the GSI was highest in April

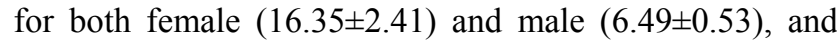
lowest in August for both female $(1.87 \pm 0.67)$ and male $(0.88 \pm 0.50)$ is similar trend with Acheilognathus signifer.

The reproductive cycle of fish is affected by external factors such as water temperature and day length, thus most fish spawn during the period when their offspring are most likely to survive from the external environment. Fish could be classified into five categories in respect of their spawning phase - spring spawner, spring-summer spawner, summer spawner, autumn spawner, spring/autumn spawner and winter spawner (Aida, 1991). For the Acheilognathinae subfamily, three categories are identified to date: spring spawner, summer spawner, and autumn spawner (Asahina et al., 1980, Shimizu \& Hanyu, 1981, Song \& Kwon, 1989).

The study subject, Aceilognathus majusculus, has highest GSI during spring (February-April) and lowest GSI during summer (July-August) when water temperature rises. It indicates that Aceilognathus majusculus shows the characteristics of a spring spawner fish, where warm water is a major Determinant on 
spawning initiation and day length is the complement to catalyze spawning (Shimizu \& Hanyu, 1993).

One of the characteristics of Acheilognathinae subfamily's external genitalia is the development of ovipositor that serves to facilitate spawning on shellfish, its symbiosis. Ovipositor in Aceilognathus majusculus appeared in December, grew largest in April (79.68 $\pm 4.69 \%$ ), gradually decreased during May-June spawning, and was completed in absent in August. The ovipositor length follows the development of gonads, so as the gonads mature, the ovipositor lengthens. Thus, it is understandable that it repeats to lengthen and shorten according to the spawning cycle.

Investigating the sexual maturation of gonads, female Aceilognathus majusculus showed only chromatin-nucleolus, peri-nucleolus, and yolk vesicle between August and December. Then primary yolk globule appeared in January, secondary yolk globule in February, tertiary yolk globule in March, mature oocyte in April, ovulated follicle in May and June, and atretic follicles in July. We concluded that female Aceilognathus majusculus's reproductive cycle shows four stages without a distinctive resting phase: growing phase (August to December), and mature phase d (January to March), ripe (April) and spawning phase (May to June), and degenerative phase (July).

Acheilognathus signifer also showed similar reproductive cycle: maturation phase (March to April), Ripe and spawning phase (May and June), degenerative and resting (July to August), and growing phase (September to October). (Baek et al., 2003).

Male Acheilognathus majusculus showed mitoting spermatogonia only in September, then primary spermatocyte and secondary spermatocyte during meiosis in October and November, spermatid cells in December until February, Spermatozoa within cavity in March and April. Spawning occurred in May and June, while degenerating sperms remained in July, and in August remaining degenerating sperms and new spermatogonia were seen among tubule epithelium. Thus the reproductive cycle of male Acheilognathus majusculus could be classified as: resting phase (September to November), growing phase (December to February), and mature phase (March to April), ripe and spawning phase (May to June), degenerative phase (July to August).

Rhodeus uyekii has five stages of reproduction: degenerative and resting phase (July to August), primary growing phase (September to November), quiescent phase (December), secondary growing and mature phase (January to February), and ripe and spawning phase (March to June). However, the five stages are different from our study, indicating that gonad development of different species is affected differently by the environment factors.

Fish could be classified as synchronous, group-synchronous, and asynchronous based on spawning habit (Wallace $\&$ Selmen, 1981). Synchronous development only has one type of developing oocyte within the ovary, and when matured it ovulates once at a specific timing. Group-synchronous development has two distinct oocyte under development. Asynchronous development has various types of oocytes within the ovary, a characteristics of multiple-spawning fish species (Shimizu et al., 1994). Rhodeus uyekii (An, 1995) and Acheilognathus signifer (Baek, 2003) are asynchronous development type with multiple spawning habit, while Acheilognathus koreensis is a synchronous development type with single spawning habit.

Acheilognathus majusculus shows various stages from chromatin-nucleolus to yolk vesicles year long, and primary yolk globule in January, secondary in February, tertiary in March, and finally mature oocyte in April to June. Thus it represents typical asynchronous ovarian development type. Since all samples had ovulated follicles during May and June, the possibility of multiple spawning is high - mimicking Rhodeus uyekii and Acheilognathus signifer.

Acheilognathus majusculus was classified as a new species by examining the nuptial coloration, gill raker, vertebral marrow, length of moustache, and shape of mouth (Kim, and Yang, 1998). As different species that live in a same habitat differentiate, not only the prey and ecological hie- 
rarchy should be distinct, but also reproductive segregation is important. The Acheilognathinae subfamily spawns inside shellfish, and the species have different preference on the shellfish type (Song \& Kwon, 1994; Kim et al., 2013). Acheilognathus yamatsutae spawns through January to August and mainly in March to May, but Acheilognathus majusculus has the main spawn phase at May to June. The difference in spawning phase is highly likely to be the reason of speciation, but more research is needed to confirm the possibility.

The Acheilognathinae subfamily reproductive cycle has not been thoroughly studied, though their endemic nature gives strong reason for utmost importance. This study hopes to contribute to species preservation of Acheilognathinae subfamily fish by defining their reproductive cycle. This results of this study will also contribute to the conservation of genetic resources in Korean endemic species.

\section{REFERENCES}

Aida K (1991) Environmental regulation of reproductive rhythms in teleosts. Academia Sinica Monograph 16: 173-187.

An CM (1995) Reproductive cycle of the spring-spawning bitterling, Rhodeus uyekii(Pisces : Cyprinidae). Korea J Ichthyol 7:33-42.

Kim CH, Choi WS, Kim DH, Beak JM (2014) Egg development and early life history of korean endemic species, Acheilognathus majusculus (Acheilognathinae). Korea J Ichthyol 26:17-24.

Song HB, Kwon OK (1989) Study on the deposition and development characters of Acheilognathus yamatsutae Mori (Cyprinidae) from the lake Uiam. Korea J Limnology 22:51-70.

Song HB, Kwon OK (1994) Spawning of the bitterling, Acheilognathus yamatsutae(Cyprinidae) into the Mussel. Korea J Ichthyol 6:39-50.

Kim HS, Yang H, Park JY (2013) Host species preference
Acheilognathus signifier(Pisces: Acheilognathus) for spawning in freshwater mussels. Korea J Ichthyol 25: 208-215.

Beak HM, Song HB, Kwon OK (2003) Sexual maturation and the spawning season of the Korean bitterling, Acheilognathus signifier in upper reachs of the Hongcheon River. Korea J Ichthyol 15:278-288.

Kim IS, Choi Y, Lee CY, Lee YJ, Kim BJ, Kim JH (2005) Illustrated Book of Korean Fishes. Kyohak publishing $106-107 \mathrm{pp}$.

Kim IS, Yang H (1998) Acheilognathus majusclus, a new bitterling(pisces: Cyprinidae) from Korea, with revised key to species of the genus Acheilognathus of Korea. Korean J Biological Science 2:27-31.

Kiyoshi A, Ikuo I, Isao H, Takash H (1980) Annual reproductive cycle of a Bittering, Rhodeus ocellatus ocellatus. Japanese Soc Sci Fish 46:299-305.

N' Da K, Deniel C (1993) Sexual cycle and seasonal changes in the ovary of the red mullet, Mullus surmuletes, from the southern coast of Brittany. Journal fish Biology 43: 229-244.

Jeong SY, Shin SH, Jin YG, Ju SM, Lee JS (2006) Abnormality of reproduction and organ structure of the oily bitterling, Acheilognathus koreensis from Isa stream. Korea J Ichthyol 18: 87-96.

Shimizu A, Isao H (1981) Annual reproductive cycle of a spring-spawning bittering, Acheilognathus tabira. Japanese Soc Sci Fish 48:1563-1568.

Shimizu A, Isao H (1993) Factors involved in the development of and decline in photoperiodism as it relates to the gonadal activity of spring-spawning bitterling, Acheilognathus tabira. Journal of Exp Zool 265:134-143.

Shimizu A, Aida K, Isao H (1994) Effects of photoperiod and temperature on gonadal activity and plasma steroid levels in an autumn-spawning bitterling, Acheilognathus rhombea, during different phase of its' annual reproductive cycle. Gen Comp Endocrinol 93:137-150.

Wallace RA, Selman K (1981) Cellular and dynamic aspects 
of oocyte growth in teleost. American Zoologist 21:325343.

Lee TY, Hanyu I, Furukawa K (1984) Effect of photoperiod and temperature on the gonadal activity in small filefish, Rudarius ercodes. Korea fish Soc 17:523-528.
Jin YG, Kim CH, Lee CW, Kim JW, Lee JS (2008) Change of external reproductive parameters according to sexual maturation of the striped bitterling, Acheilognathus yamatsutae (Teleostei: Acheilognathinae). Korea J Ichthyol 20:13-20. 